\title{
Identifying client project manager competency in Indonesian construction project
}

\author{
Kartika Puspa Negara ${ }^{1, *}$, Fiona Lamari $^{1}$, Connie Susilawati ${ }^{1}$, and Bambang Trigunarsyah $^{2}$ \\ ${ }^{1}$ Civil Engineering and Built Environment School, Queensland University of Technology, Brisbane, \\ Australia \\ ${ }^{2}$ School of Property, Construction, and Project Management, RMIT University, Australia
}

\begin{abstract}
The influence of active client involvement towards project construction success is gaining recognition in the last few decades. The growing concern on the client involvement has drifted the perception towards client away from the passive role into contributor of project success. During client involvement in the construction project, a representative from client or client project manager (CPM) should be complemented with certain competencies in order to succeed in commissioning construction projects. Evidence shows that some public construction projects in Indonesia failed due to the lack of competency of client project managers. Whilst most of the previous studies concern on the competency of general project managers, this paper specifically investigates competency of project manager from client side who works as a civil servant, and commissioning public construction sectors. This paper aims to identify the important competencies required by CPM in construction projects in Indonesia and examine current Indonesian CPM competency standard. Relative Importance Index (RII) was employed to assess the important level of competencies. The findings will enrich understanding on client project manager competency and become a basis to undergird further empirical research in client project manager development areas.
\end{abstract}

\section{Introduction}

A successful construction projects start with the clients [1]. The involvement of clients since the early stage of the construction projects influence projects success. However, the involvement of clients might exacerbate the project outcomes. According to Odeh et al. [2], client interference during the involvements might lead to the delay in the project delivery. In agreement with them, Salleh [3] outlined that client-initiated variations, slowness of client's decision-making process, delay in revising and approving design by the client, poor client communication are some factors induced by clients which impact on project delay.

In Indonesian public construction projects, Indonesian government as a client pay attention to the involvement of client for contributing project success. The representative of client or client project manager is assigned with a set of responsibilities and competencies

\footnotetext{
* Corresponding author: kartikapuspa.negara@,hdr.qut.edu.au
} 
to engender project success. However, recently a local government had investigated 53 projects that were inflicted financial loss and found that the lack of technical competency of client project managers during clients involvement as one of the sources of the project's problems [4].

There are myriad numbers of studies discuss project manager competency, e.g. [5-7]. However, only a few of them focus on project manager from the client side, especially from government employees. The objectives of this paper are to identify the important competencies required by $\mathrm{CPM}$ in construction projects in Indonesia and examine the current Indonesian CPM competency standard. First, a review of project manager competency literature and Indonesian CPM competency standards is presented, followed by the research methodology, and data analysis techniques. After that, the research findings are discussed, concluded by presenting the contribution, and limitation of this research.

\section{Literature review}

\subsection{Competency of project managers in construction projects}

An unsuccessful project should not merely be addressed to the consultant, but the client might also responsible for not possessing the attributes required to achieve project success [8]. Kometa et.al [8] investigated UK construction clients to find important client attributes influencing consultant's performance, one of them is related to client's duties which consist of project definition and formulation, planning and design, finance, project implementation, politics and social factors, schedule urgency, human factors, project duration, legal agreements, and contracting.

The importance of client competency also discussed in some literature, for instance in Lim et al. [9]. They assert that clients who able to define project objectives clearly are more likely contributing to project success. In their studies, they investigate the client's contribution to project success based on 17 contractors and 16 consultants' perception in Singapore. They state that client's management competency can have significant effects upon project success alongside with client's financial status, characteristics, and construction experiences.

In this research, client project manager defined as "a person working in public sector who has been delegated by the client to act on his/ her behalf to engage with other parties, implement the contract, and ensuring the client requirements is fulfilled" [10]. In order to fulfill the duties, client project manager should be supplemented with a set of required competency.

Based on construction management literature, the knowledge competencies required by construction project managers that addressed by most of the researchers are time management, quality, risk management, human resource, cost management, material or supply chain management, and conflict, dispute, claim management. Some competencies required by construction project manager that fewer authors addressed are procurement management, organization management, health and safety, and scope management [5-7, 11]. Meanwhile, some skills/ behavior required by construction project managers that most of the authors acknowledge are delegation, leadership, decision making, team working, and communication $[6,12,13]$.

\subsection{Client project manager competency in Indonesian standard}

Until this paper written, procurement in Indonesia refers to the recent amendment of Presidential Regulation No.16 of 2018 on the procurement of good/ service. According to 
this regulation, PPK (Commitment-Making Officer or in this research refers to the Client Project Manager) is one of the parties involved in the public procurement of goods or services.

National competency standard in Indonesian procurement is stipulated by Ministerial Decree No.70 of 2016. This standard applies for all project management team involved in public projects in Indonesia. Recently the government issued specific CPM competencies in public procurement of goods or services in Indonesia. The competency consists of 1) Plan technical specification, 2) Plan owner estimate, 3) Review procurement package of good/ service, 4) Draft Contract, 5) Evaluate performance of supplier of good/ service, 6) Finalize contract documents, 7) Establish contract team management, 8) Plan contract administration, 9) Control contract, 10) Resolve disputes, 11) Receive project completed, 12) Prepare in-house/swakelola procurement, 13) Implement in-house/ swakelola procurement, (14) Manage project performances, and 15) Manage project risks [14].

\section{Methodology}

A self-administered questionnaire survey was developed to identify competencies required by client project manager in the construction projects. The questionnaire was validated through pilot-questionnaire before it was administered to 131 construction client project managers in East Java, Southeast Sulawesi and Gorontalo Provinces, Indonesia. All of $\mathrm{CPM}$ are civil servants working in various government agencies and has experience in managing construction projects in Indonesia. A response rates $68 \%$ was retrieved, and then analyzed using relative importance index. Relative importance index (RII) was adopted to obtain the level of importance [15].

$$
R I I=\frac{\sum w}{A N}
$$

where $w$ is the weighting for each factor given by respondents, ranging from 1 (not important) to 5 (very important), $A$ is the highest weight (in this study is 5), and $N$ is total respondents. In this research, RII is obtained by dividing the mean of weighting with the highest weighting (i.e. 5 in this case) [15],

$$
R I I=\frac{\text { Mean }}{A}
$$

The result is divided into three level of importance: high $(\mathrm{H}): 0.8 \leq \mathrm{RII} \leq 1$, medium (M): $0.5 \leq \mathrm{RII}<0.8$, and low (L): $0 \leq \mathrm{RII}<0.5$. The result acquired from empirical data is compared to (1) the current Indonesian CPM competency standard and (2) the list of competencies of construction project manager identified through literature review.

Twenty-three main attributes of construction project managers competencies was analyzed, comprise of 1) scope management, 2) schedule management and planning, 3) cost management, 4) human resource management, 5) risk management, 6) quality management, 7) stakeholder management, 8) communication management, 9) conflict, claim and dispute management, 10) health, safety, and environment, 11) procurement management, 12) material, plant, and equipment resource management, 13) Information technology management 14) ethical management, 15) technical-area competency, 16) delegation, 17) leadership, 18) decision-making, 19) problem-solving, 20) teamwork, 21) analytical, 22) integrity, and 23) negotiation. 17 of the 23 competencies result in high level of importance. Table 1 presents the findings of competencies required by CPM with a high level of importance. 
Table 1. Important client project manager competencies perceived by CPM.

\begin{tabular}{|c|c|c|c|c|}
\hline No & Competency areas & Mean & RII & Important level \\
\hline 1 & Scope management & 4.13 & 0.83 & $\mathrm{H}$ \\
\hline 2 & Schedule management and planning & 4.05 & 0.81 & $\mathrm{H}$ \\
\hline 3 & Cost management & 4.25 & 0.85 & $\mathrm{H}$ \\
\hline 4 & Human Resource management & 3.99 & 0.80 & $\mathrm{H}$ \\
\hline 5 & Risk management & 3.99 & 0.80 & $\mathrm{H}$ \\
\hline 6 & Quality management & 4.25 & 0.85 & $\mathrm{H}$ \\
\hline 7 & Procurement management & 4.02 & 0.80 & $\mathrm{H}$ \\
\hline 8 & Ethical management & 3.99 & 0.80 & $\mathrm{H}$ \\
\hline 9 & Technical-area competency & 4.31 & 0.86 & $\mathrm{H}$ \\
\hline 10 & Delegation & 4.07 & 0.81 & $\mathrm{H}$ \\
\hline 11 & Leadership & 4.30 & 0.86 & $\mathrm{H}$ \\
\hline 12 & Decision-making & 4.34 & 0.86 & $\mathrm{H}$ \\
\hline 13 & Problem solving & 4.15 & 0.83 & $\mathrm{H}$ \\
\hline 14 & Teamwork & 4.35 & 0.87 & $\mathrm{H}$ \\
\hline 15 & Analytical & 4.10 & 0.82 & $\mathrm{H}$ \\
\hline 16 & Integrity & 4.22 & 0.84 & $\mathrm{H}$ \\
\hline 17 & Negotiation & 4.12 & 0.82 & $\mathrm{H}$ \\
\hline
\end{tabular}

The comparison of project managers competencies identified from literature review, Indonesian CPM competency standard, and the empirical results are in Table 2.

\section{Results and discussion}

Indonesian CPM competency standard takes predefined areas of competencies as a point of departure and using functional-based approach to assess CPM competency. Compared to the empirical research, few competencies are not addressed in the standard, which are:

1) Communication management: There is no specific communication management competency unit in the national standard. However, communication management is included as a subsection under two competencies units: 1) plan technical specification and 2) manage project performance competency unit.

2) Health, Safety, and Environment Management: There is no specific health, safety, and environment management competency unit in the national standard. However, communication management is included as a subsection under a competency unit: plan contract management competency. 
Table 2. Comparison of CPM competency.

\begin{tabular}{|c|c|c|}
\hline $\begin{array}{c}\text { PM competency } \\
\text { (Literature review) }\end{array}$ & $\begin{array}{c}\text { Indonesian CPM } \\
\text { competency standard (areas) }\end{array}$ & $\begin{array}{c}\text { Important CPM competency } \\
\text { (empirical research) }\end{array}$ \\
\hline 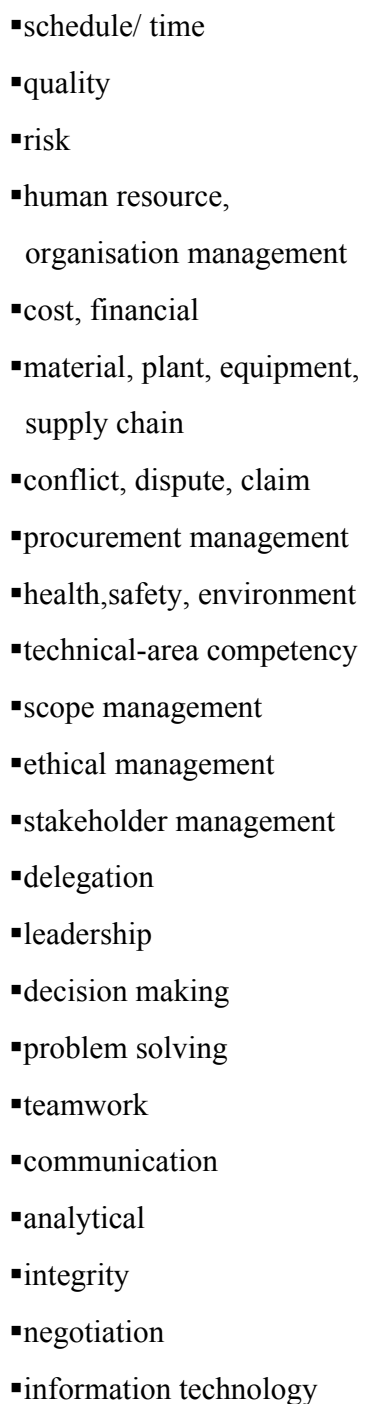 & $\begin{array}{l}\text {-cost management } \\
\text {-technical specification } \\
\text { (quality, quantity, time, } \\
\text { service level) } \\
\text {-procurement (including in- } \\
\text { house/swakelola } \\
\text { management) } \\
\text {-contract management } \\
\text {-performance level of supplier } \\
\text { management } \\
\text {-team management } \\
\text {-dispute resolution } \\
\text {-risk management }\end{array}$ & $\begin{array}{l}\text {-technical-area competency } \\
\text {-cost management } \\
\text { - quality management } \\
\text {-scope management } \\
\text {-schedule management and } \\
\text { planning } \\
\text {-risk } \\
\text {-human Resource } \\
\text {-ethical management } \\
\text {-procurement } \\
\text {-teamwork } \\
\text {-decision-Making } \\
\text {-delegation } \\
\text {-leadership } \\
\text {-integrity } \\
\text {-problem Solving } \\
\text {-negotiation } \\
\text { - analytical }\end{array}$ \\
\hline
\end{tabular}

3) Stakeholder management: There is no specific stakeholder management competency unit in the national standard. However, communication management is included as a subsection under a competency unit: manage project risk competency.

4) Ethical Management: There is no specific ethical management competency unit in the national standard. However, ethics is included in a subsection under norm and standard in each competency units.

5) Behavior: Since Indonesian national standard use functional-based approach, the behavior is inherent in each task required. 
It is interesting to note that aforementioned competencies: communication; health, safety, and environment management; and stakeholder management, are not perceived as competencies with the high level of importance by CPMs, but technical-area is regarded as the most important knowledge-skill competency. This finding is contrary to El-Sabaa [16] who concluded that technical competency is the least essential competency of project manager. This different result may be due to the nature of Indonesian CPM duties. They have to establish technical specification, contract, and owner estimate regardless of their academic discipline. Even though they can be assisted by a technical team, but a CPM should be responsible for the results. This research finding is in accord with a recent fact that a lack of CPM technical competency was one of the sources of 53 Indonesian public projects afflicted with state financial loss problem [4].

Another knowledge competencies that are considered as important perceived by CPM are cost management, quality, schedule, scope, resource, risk, procurement, and ethical management. Regarding behavior competency, teamwork is regarded as the most important competency followed by decision-making, leadership, integrity, problem solving, and negotiation. This result may be explained by the fact that a CPM works together with other parties involved in a public project to achieve project success(e.g. PjPHP/PPHP/official receiving project results, and procurement officers). These important behavior competency perceived by CPM is not written as a separate unit in Indonesian CPM competency standard. It is because the standard using functional-based approaches.

\section{Conclusions}

This research examined Indonesian CPM competency standard and identified important competencies required by CPMs in the construction projects areas. The current findings highlight the importance of technical-area competency and teamwork competency to be possessed by CPMs. Although the identified competencies are perceived by CPMs solely, this research complement earlier project manager studies by emphasizing on the competency of clients side in Indonesian public construction context. The research could lay the groundwork for further research in training and development needs to improve client project manager competency.

The research is funded by Queensland University of Technology Postgraduate Research Award (QUTPRA).

\section{References}

1. S.M. Alsolaiman, An empirical study of the factors impacting on the involvement of clients in Saudi Arabian construction projects (Queensland University of Technology, Brisbane, 2014)

2. A.M. Odeh, H.T. Battaineh, Int. J. Proj. Manag. 20,1 (2001)

3. R. Salleh, Critical success factors of project management for Brunei construction projects: improving project performance (Queensland University of Technology, Brisbane, 2009)

4. Jawa Pos, Kompetensi pengawas dan PPK kurang (2017)

5. R. Dobgegah, D.-G. Owusu-Manu, K. Omoteso, Australas. J. Con. Econ. Build. 11, 1 (2011)

6. B.-G. Hwang, W.J. Ng, Int. J. Proj. Man. 31, 2 (2013)

7. P. Chen, D. Partington, Int. J. Proj. Man. 24, 5 (2006) 
8. S.T. Kometa, P.O. Olomolaiye, F.C. Harris, Constr. Man. Econ. 12, 5 (1994)

9. E. Hwee Lim, F.Y.Y. Ling, Eng., Con. and Architectural Man. 9, 5/6 (2002)

10. K.P. Negara, F. Lamari, B. Trigunarsyah, Malaysian Constr. Res. J. 29, 3 (In Press, 2019)

11. L. Crawford, Proc. of PMI Research Conference (2000)

12. D. Arditi, G. Balci, J. Constr. Eng. Man. 135, 11(2009)

13. K.T. Odusami, J. Manag. Eng. 18, 2 (2002)

14. LSP LKPP, Skema Sertifikasi Kompetensi Pejabat Pembuat Komitmen Pengadaan Barang/Jasa (PPK PBJ). Indonesia, 2017.

15. Z. Shari, Development of a sustainability assessment framework for Malaysian office buildings using a mixed-methods approach (The University of Adelaide, Adelaide, 2011)

16. S. El-Sabaa, Int. J. Proj. Man. 19, 1 (2001) 